\title{
Altered regulation of PDK4 expression promotes antiestrogen resistance in human breast cancer cells
}

\author{
William Walter ${ }^{1}$, Jennifer Thomalla', Josh Bruhn¹, Dedra H. Fagan², Cheryl Zehowski', Douglas Yee² \\ and Andrew Skildum ${ }^{1,2^{*}}$
}

\begin{abstract}
Acquired or de novo resistance to the selective estrogen receptor modulators tamoxifen and fulvestrant (ICI) is a major barrier to successful treatment of breast cancer. Gene expression patterns in tamoxifen resistant (TamR-MCF-7) cells were compared to their parental cells (MCF-7L) to identify an aberrantly regulated metabolic pathway. TamRMCF-7 cells are cross resistant to ICl and doxorubicin, and have increased mitochondrial DNA. A small subset of genes had altered expression in TamR-MCF-7 relative to MCF-7L cells. One of the genes, pyruvate dehydrogenase kinase-4 (PDK4), phosphorylates pyruvate dehydrogenase (PDH). PDK4 expression was elevated in TamR-MCF-7 cells; this result was also observed in a second model of acquired antiestrogen resistance. PDK4 expression is controlled in part by glucocorticoid response elements in the PDK4 gene promoter. In MCF-7L cells, PDK4 mRNA expression was insensitive to glucocorticoid receptor agonists, while dexamethasone dramatically increased PDK4 expression in TamR-MCF-7 cells. Using siRNA to knock down PDK4 expression increased TamR-MCF-7 sensitivity to ICl; in contrast adapting cells to growth in glucose depleted media did not affect ICI sensitivity. Despite TamR-MCF-7 cells high levels of PDK4 mRNA relative to MCF-7L, TamR-MCF-7 cells have increased PDH activity. Wild type MCF-7 cells are reported to be heterozygous for a $\mathrm{G}$ to $\mathrm{A}$ mutation that results in a substitution of threonine for alanine near PDK4's catalytic site. We found loss of heterozygosity in TamR-MCF-7 cells; TamR-MCF-7 are homozygous for the wild type allele. These data support a role for altered regulation of PDH by PDK4 and altered substrate utilization in the development of drug resistance in human breast cancer cells.
\end{abstract}

Keywords: Breast cancer, Metabolism, Pyruvate dehydrogenase kinase-isoform 4 (PDK4), Antiestrogen resistance, Glucose

\section{Background}

Therapies that target the estrogen receptor- $\alpha$ (ER) have resulted in significant improvement in clinical outcomes for breast cancer patients (Early Breast Cancer Trialists' Collaborative G 2005; Strasser-Weippl et al. 2013). These endocrine therapies include selective estrogen receptor modulators (SERMs) such as tamoxifen (Jordan and Koerner 1975), molecules that downregulate ER (e.g. fulvestrant Wakeling et al. 1991), and aromatase inhibitors

\footnotetext{
*Correspondence: askildum@d.umn.edu

${ }^{1}$ Department of Biomedical Sciences, University of Minnesota Medical

School, Duluth Campus, Duluth, MN, USA

Full list of author information is available at the end of the article
}

that reduce expression of the endogenous ER ligand estradiol (Wells et al. 1978; Lipton et al. 1995). Despite these gains, recurrence of breast cancer after endocrine therapy is a major barrier to eliminating breast cancer mortality (Jordan and O’Malley 2007; Arpino et al. 2009; Moy et al. 2015). Mechanisms proposed for the development of resistance to ER targeted drugs include altered splicing or mutation of ER (Han et al. 2004; Scott et al. 1991; Banerji et al. 2012), reduced ER expression (Bayliss et al. 2007; Chu et al. 2007; Oh et al. 2001), aberrant tamoxifen metabolism (Osborne 1993; Osborne et al. 1992), altered function of cell cycle proteins regulating the G1 to S phase progression (Lehn et al. 2011; Abukhdeir et al. 2008; Varma et al. 2007; Mukherjee and Conrad

\section{黛 Springer}


2005; Wilcken et al. 1997), altered interactions of scaffold proteins with downstream signaling proteins (Wallez et al. 2014; Brinkman et al. 2000), deregulated growth factor signaling (Fagan et al. 2012; Brockdorff et al. 2003), upregulated NF-kB signaling (Riggins et al. 2005), androgen receptor upregulation (Fujii et al. 2014), and activated Myc signaling (Mukherjee and Conrad 2005; Miller et al. 2011; Shajahan-Haq et al. 2014). Despite the many routes to endocrine therapy resistance in in vitro models, the clinical significance is less clear and has not led to predictive biomarkers or effective therapies to prevent or overcome resistance (Droog et al. 2013).

In the last two decades there has been a resurgence of interest in tumor metabolism as an exploitable target for cancer therapy, and metabolic abnormalities are now in the canon of hallmarks of cancer (Hanahan and Weinberg 2011; DeBerardinis et al. 2008). Cancers are generally more glycolytic than normal tissue, and this was originally interpreted as a compensatory response to defects in respiration (Cook and Higuchi 2012). One consequence of increased glycolysis is extracellular acidification, and this has been shown to cause insensitivity to endocrine therapies (Yang et al. 2013). Oncogenes and cell cycle regulatory proteins have been shown to regulate the metabolism of fuels in addition to cellular proliferation, with consequences for endocrine therapy in breast cancer cells (Shajahan-Haq et al. 2014; Lee et al. 2014; Wang et al. 2006). Cancer metabolism is diverse, and clinically the mitochondrial DNA (mtDNA) content of breast cancer varies with stage, with early and advanced stage cancers having higher mtDNA than those diagnosed at intermediate stage (Bai et al. 2011). This observation suggests that as cancers progress, they become more reliant on mitochondrial function. Consistent with that notion, malignant breast cancer cells are metabolically coupled with tumor associated fibroblasts, with fibroblasts fermenting substrates and providing lactate for oxidation by cancer cells; this relationship promotes SERM resistance (Martinez-Outschoorn et al. 2011). Taken together, these observations suggest that fuel metabolism is plastic in breast cancer cells, and that utilization of fuels impacts response to endocrine therapy.

A major determinant of fuel choice is the pyruvate dehydrogenase complex (PDH), an enzyme that converts pyruvate and coenzyme A to acetylCoA and carbon dioxide, reducing one $\mathrm{NAD}^{+}$to $\mathrm{NADH}$ in the process. Different PDH subunits perform the decarboxylation, acyl transfer and oxidation/reduction reactions, and each subunit has cofactor requirements specific for their function. In addition to the abundance of substrate and product, PDH activity is also regulated by phosphorylation and dephosphorylation of the E1 subunit with inactivation of enzymatic activity by phosphorylation. The balance of kinase and phosphatase activities determines the PDH phosphorylation status. Four isoforms of pyruvate dehydrogenase kinase (PDK) are known, each active in response to different intracellular and extracellular conditions. PDK1 is activated by hypoxia (Mora et al. 2003; Kim et al. 2006); PDK2 is activated by the PDH products acetyl CoA and NADH and is inhibited by ADP and pyruvate (Hiromasa et al. 2006); and PDK3 is activated by ATP (Kato et al. 2005). Pyruvate dehydrogenase kinase-isoform 4 (PDK4), in contrast, is activated transcriptionally by hormonal signals such as retinoic acid and glucocorticoids, and transcriptionally repressed by insulin (Kwon et al. 2004). Thus while regulation of PDK1-3 reflects the immediate energy demands of the cell, PDK4 is reflective of whole organism energy balance and is upregulated in metabolic conditions such as hibernation (Buck et al. 2002), sustained exercise (Wang and Sahlin 2012; Pilegaard and Neufer 2004), and diabetes (Wu et al. 1998).

We previously reported that mitochondrial DNA copy number and mitochondrial superoxide were amplified in LCC9 cells, a cell line sequentially selected from parental MCF-7 cells for estrogen independence and fulvestrant resistance (Brunner et al. 1997; Skildum et al. 2011). We reasoned that mitochondrial amplification was a response to altered fuel metabolism, and that SERM resistant breast cancer cells would have altered expression of genes that regulate carbohydrate metabolism. In an independent model of acquired SERM resistance using cells selected directly from parental MCF-7 for growth in the presence of 4-hydroxytamoxifen (Fagan et al. 2012), we used quantitative PCR (qPCR) arrays to compare the expression of genes that regulate glucose metabolism. PDK4 expression was increased in tamoxifen resistant (TamR-MCF-7) cells, and the regulation of PDK4 by glucocorticoid receptor ligands was increased in TamR-MCF-7 cells. Paradoxically, PDH activity was also elevated in TamR cells. We found that parental MCF-7L cells were heterozygous for a mutation which causes an amino acid substitution near the PDK4 active site, and the TamR-MCF-7 cells lost heterozygosity and only expressed wild type PDK4. Decreased PDK4 expression partially restored antiestrogen sensitivity in these cells. We conclude that regulatory circuits that control oxidation of carbon derived from glucose are altered during selection for antiestrogen resistance.

\section{Methods}

\section{Cell lines and reagents}

The cell lines used are summarized in Table 1. ATCC-MCF-7 cells were obtained from the American Type Culture Collection (Soule et al. 1973). MCF-7L and TamR-MCF-7 cells were established as 
Table 1 Cell lines

\begin{tabular}{|c|c|c|c|c|}
\hline $\begin{array}{l}\text { Cell line } \\
\text { name }\end{array}$ & $\begin{array}{l}\text { Parental } \\
\text { cell line }\end{array}$ & Selection for... & Source of cells & References \\
\hline MCF-7L & & & $\begin{array}{l}\text { University of Minnesota Masonic } \\
\text { Cancer Center }\end{array}$ & \\
\hline TamR-MCF-7 & MCF-7L & $\begin{array}{l}\text { Proliferation in the presence of } \\
\text { 4-hydroxytamoxifen in vitro }\end{array}$ & $\begin{array}{l}\text { University of Minnesota Masonic } \\
\text { Cancer Center }\end{array}$ & Wallez et al. (2014) \\
\hline LCC-MCF-7 & & & $\begin{array}{l}\text { Georgetown University Lombardi } \\
\text { Cancer Center }\end{array}$ & \\
\hline LCC9 & LCC-MCF-7 & $\begin{array}{l}\text { Estrogen independent tumorigenesis } \\
\text { in vivo; Proliferation in the presence } \\
\text { of ICI in vitro }\end{array}$ & $\begin{array}{l}\text { Georgetown University Lombardi } \\
\text { Cancer Center }\end{array}$ & Pilegaard and Neufer (2004) \\
\hline ATCC-MCF-7 & & & American Type Culture Collection & Brunner et al. (1997) \\
\hline MCF-7-GAL & ATCC-MCF-7 & $\begin{array}{l}\text { Proliferation in } 4.5 \mathrm{mM} \text { galactose with } \\
\text { undetectable glucose }\end{array}$ & $\begin{array}{l}\text { Generated at University of Minnesota } \\
\text { Medical School, Duluth }\end{array}$ & \\
\hline
\end{tabular}

The origins of the cell lines used in this study are summarized

previously described (Fagan et al. 2012). LCC-MCF-7 and LCC9 cells were obtained from Dr. Robert Clarke of the Georgetown University Lombardi Cancer Center. ATCC-MCF-7, LCC-MCF-7 \& MCF-7L were routinely cultured in phenol red free IMEM with $5 \%$ fetal bovine serum (FBS), $1 \times$ penicillin/streptomycin, $6 \mathrm{ng} / \mu \mathrm{L}$ bovine pancreatic insulin (Sigma), and $2.5 \mu \mathrm{g}$ plasmocin (Invivogen). TamR-MCF-7 cells were cultured in phenol red free IMEM $+5 \%$ charcoal stripped FBS, $1 \times$ penicillin/streptomycin, $6 \mathrm{ng} / \mu \mathrm{L}$ insulin, $2.5 \mu \mathrm{g} / \mathrm{L}$ plasmocin and $10^{-7} \mathrm{M}$ 4-hydroxytamoxifen (Sigma). LCC9 cells were cultured in phenol red free IMEM $+5 \%$ charcoal stripped FBS, $1 \times$ penicillin/streptomycin, $6 \mathrm{ng} / \mu \mathrm{L}$ insulin, $2.5 \mu \mathrm{g} / \mathrm{L}$ plasmocin (Invivogen), and $10^{-9} \mathrm{M}$ fulvestrant (ICI).

MCF-7-GAL cells were generated by adapting ATCCMCF-7 to progressively increased concentrations of galactose and decreased concentrations of glucose. Initially cells were cultured in DMEM (Sigma catalog number D5030) supplemented with $2 \mathrm{mM}$ glutamine, $1 \mathrm{mM}$ pyruvate, $5 \% \mathrm{FBS}, 1 \times$ penicillin/streptomycin, $12.5 \mathrm{mM}$ $\mathrm{D}$-glucose and $12.5 \mathrm{mM} \mathrm{D}$-galactose; the concentration of glucose in this media is half that in MCF-7's normal media. Over the course of 2 months, cells were allowed to grow to confluence, then split into new plates with progressively lower concentration of glucose and higher concentrations of galactose, until a population of cells was derived (MCF-7-GAL) that grew as rapidly in $25 \mathrm{mM}$ galactose media as their parental cells grew in $25 \mathrm{mM}$ glucose. In the $25 \mathrm{mM}$ galactose media, some glucose was provided by FBS, however, the glucose concentration in this media was below the detection limit of a glucose oxidase based colorimetric assay (data not shown).

D-glucose, D-galactose, dexamethsone, mifepristone, 4-hydroxytamoxifen, and ICI were purchased from Sigma.

\section{Western blots}

MCF-7L and TamR-MCF-7 were treated as described, and whole cell lysates were prepared in RIPA buffer supplemented with protease inhibitor cocktail, phenylmethanesulfonylfluoride, and sodium fluoride (all purchased from Sigma). Lysates were sonicated and cleared by high speed centrifugation. Protein concentration in the supernatants was determined by Bradford assay (BioRad), and equal quantities of protein were diluted in 6x-SDS-PAGE buffer and boiled. Lysate equivalent to $40 \mu \mathrm{g}$ protein were resolved on $10 \%$ SDS polyacrylamide gel (TGX gels, Bio$\mathrm{Rad})$, then transferred to polyvinylidene fluoride membrane. The membrane was blocked with $5 \%$ nonfat dry milk in phosphate buffered saline with $1 \%$ Tween-20 (PBS-T; Tween-20 purchased from Sigma). Membranes were incubated overnight at 4 degrees with anti-PDK4 antibody (Abgent Cat. No. AP7041B) diluted at 1:1000 in blocking solution. The membrane was washed thrice with PBS-T, then incubated for $1 \mathrm{~h}$ with horseradish peroxidase conjugated secondary antibody diluted 1:1000 in blocking solution. The membrane was washed thrice with PBS-T, then incubated with enhanced chemiluminescence reagents for 2 min (SuperSignal West Pico; Pierce). Antibody interactions were visualized by exposing the membrane to film. The membrane was then washed with PBS-T and, using the procedure described above, probed for actin to ensure equal loading (Sigma clone AC-40). The images in Fig. 1b were generated by scanning films with a flatbed scanner.

\section{Cell cycle assay}

MCF-7L and TamR-MCF-7 cells were plated at $10^{6}$ per $10 \mathrm{~cm}$ dish in MCF-7L's normal growth media (permissive media for both cell lines). After attaching overnight, $1 \mathrm{~nm} \mathrm{ICI}$ or vehicle (DMSO) was added to the cells without changing media. After $48 \mathrm{~h}$, cells were harvested by 


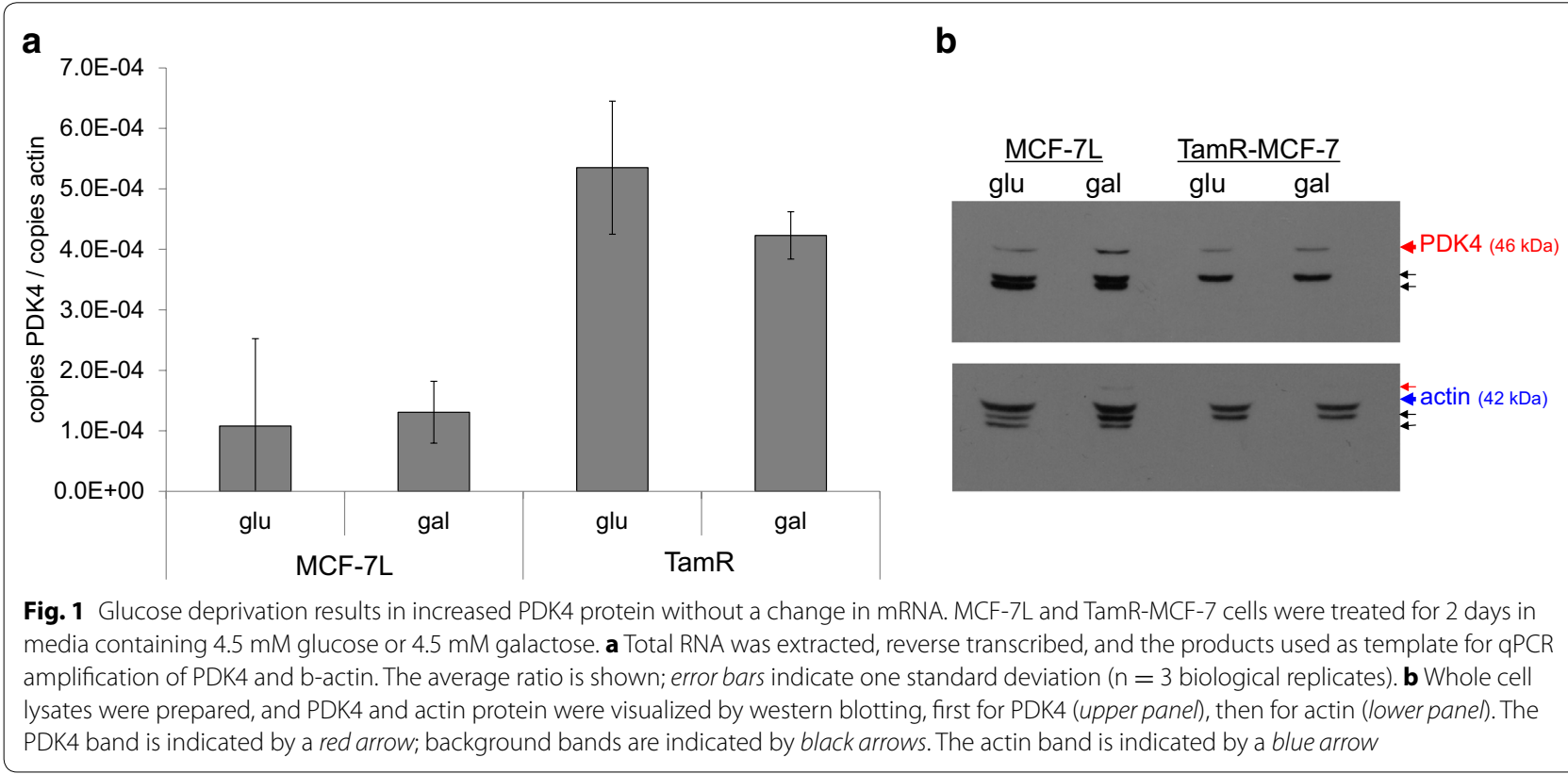

trypsinization and fixed in ethanol. Cells were then centrifuged and the fixative removed by aspiration. The cell pellet was resuspended in $0.4 \mathrm{~mL}$ fluorescence-activated cell sorting buffer $(1.37 \mathrm{M} \mathrm{NaCl}, 27 \mathrm{mM} \mathrm{KCl}, 43 \mathrm{mM}$ $\mathrm{Na} 2 \mathrm{HPO} 4,14.7 \mathrm{mM} \mathrm{KH} 2 \mathrm{PO} 4,1 \mathrm{mg} / \mathrm{mL}$ ribonuclease A, $0.5 \mathrm{mM}$ EDTA, $0.1 \%$ Triton $\mathrm{X}-100$, and $0.2 \mathrm{mg} / \mathrm{mL}$ propidium iodide), pipetted several times to ensure a uniform single-cell suspension, and transferred to a polystyrene tube. Cells were incubated at $4{ }^{\circ} \mathrm{C}$ in the dark for 30 min before analysis.

Cells were analyzed on a FACS Caliber flow cytometer, and data were collected using CellQuest Pro software (Becton-Dickinson). Cells were gated on forward and side scatter to eliminate debris and on the width versus area of the red fluorescent voltage pulse to eliminate cell aggregates. The area of the red fluorescence voltage pulse for the gated cells is proportional to their DNA content, and the cell cycle profile for each sample was estimated using ModFit LT software (Verity Software House). A minimum of 10,000 gated cells were analyzed for each sample, and triplicate parallel cultures were analyzed for each treatment.

\section{siRNA transfection and sulforhodamine $B$ assays}

TamR-MCF-7 cells were plated at 10,000 cells per well in 24 well plates in MCF-7L cells' normal growth media. After overnight attachment, cells were transfected with one of two PDK4 siRNAs (Qiagen Flexitube Hs_PDK4_6 and Hs_PDK4_7) or a non-specific control siRNA using Lipofectamine 2000 (Invitrogen) according to the vendor's protocol.
To validate efficacy of PDK4 knockdown, cells were treated with $1 \mathrm{nM}$ dexamethasone or ethanol vehicle 1 day after transfection. Two days after treatment, total RNA was collected, reverse transcribed to cDNA, and used as template for qPCR amplification of PDK4 and actin using the methods described above.

One day after transfection cells were treated with 1 and $5 \mathrm{nM} \mathrm{ICI}$ or DMSO vehicle to test the effects of PDK4 knockdown on antiestrogen sensitivity. Four days later, cells were washed with PBS, then fixed in $10 \%$ trichloroacetic acid for $30 \mathrm{~min}$ at $4{ }^{\circ} \mathrm{C}$. The fixative was removed by aspiration and washing gently with tap water; the 24-well plates were then air dried. Each well was then stained with $0.4 \%$ sulforhodamine B (SRB) in $1 \%$ acetic acid at room temperature for $30 \mathrm{~min}$, then washed thrice in $1 \%$ acetic acid, and air dried. Stained proteins were then solubilized in $0.5 \mathrm{~mL} 10 \mathrm{mM}$ tris base. A $0.1 \mathrm{~mL}$ aliquot was then transferred to a 96-well microtitre plate. SRB absorbance at $565 \mathrm{~nm}$ and background absorbance at $690 \mathrm{~nm}$ were measured spectrophotometrically.

To measure doxorubicin sensitivity, cells were plated at 5000 cells per well in 24 well plates and allowed to attach overnight. Cells were then treated \pm 0.02 micromolar doxorubicin (Sigma) from freshly prepared stocks diluted in water. Cells were cultured for 4 days, and cellular abundance was measured using SRB staining as described above.

\section{Quantitative PCR arrays}

To compare gene expression patterns in parental MCF7L cells and TamR-MCF-7 cells selected for antiestrogen 
resistance, we employed qPCR arrays containing primer sets targeting 81 genes that encode enzymes that control different aspects of carbohydrate metabolism (RT2 Profiler PCR Array Human Glucose Metabolism, Qiagen). Samples of MCF-7L and TamR-MCF-7 cells were generated by thawing ampules of each cell line and growing to sub-confluence in T75 flasks. Cells were then trypsinized and plated at 500,000 cells per $10 \mathrm{~cm}$ dish and allowed to attach overnight. Cells were then cultured for 2 days. Total RNA was isolated from cells using the Qiagen RNeasy kit. Using this protocol, four independent samples from each cell line were prepared on different days to account for biological variability in gene expression. Three sample sets were used for qPCR arrays, while the fourth set was used as a validation set.

RNA quantity and quality were measured using an Agilent Bioanalyzer, a core service provided by the University of Minnesota Genomics Center. The RNA integrity number (RIN) scores ranged from 8.60 to 9.10, indicating good quality of the RNA preparations. RNA was reverse transcribed and genomic DNA eliminated using the RT2 First Strand kit (Qiagen) according to the manufacturer's instructions, and the products were used as template for qPCR arrays. The qPCR array plates were run on a Light Cycler 480 thermocycler (Roche), and data were analyzed using Microsoft Excel templates supplied by Qiagen.

\section{Pyruvate dehydrogenase activity assays}

To measure PDH activity the Pyruvate Dehydrogenase Activity Colorimetric Assay Kit from BioVision was used. On three consecutive days, identically prepared aliquots of cells were thawed from liquid nitrogen and plated on T75 tissue culture plates. Cells were grown to sub-confluence, then split into $10 \mathrm{~cm}$ tissue culture dishes and grown for 2 days.

Assays were conducted on three consecutive days. On the day of each assay, cells were harvested by scraping cells and counted on a hemocytometer. $1 \times 10^{6}$ cells were Dounce homogenized with $100 \mu \mathrm{L}$ ice cold PDH assay buffer. The samples were kept on ice for $10 \mathrm{~min}$ before being centrifuged at $10,000 \times g$ for $5 \mathrm{~min}$. The supernatant was then transferred to a fresh tube. Protein concentration in each sample was determined with the BioVision BCA Protein Assay Kit II using bovine serum albumin standards according to the manufacturer's protocols. Equal amounts of protein were added from each sample and the reaction volume was adjusted to $50 \mu \mathrm{L}$ with PDH Assay Buffer and transferred to a microtitre plate. Triplicate assays were performed on each sample, and blank reactions were included as negative controls. The plate was immediately measured with the plate reader in kinetic mode at $450 \mathrm{~nm}$ for $30 \mathrm{~min}$ at $37{ }^{\circ} \mathrm{C}$. Separately, an external NADH standard curve was prepared using the BioVision protocol where $0,2.5$, 5.0, 7.5, 10 and $12.5 \mathrm{nmol} /$ well of NADH standard was adjusted to $50 \mu \mathrm{L} /$ well with PDH assay buffer. $50 \mu \mathrm{L}$ of the reaction mix was added and immediately measured with the plate reader in equilibrium mode at $450 \mathrm{~nm}$ at $37^{\circ} \mathrm{C}$. The slopes of the kinetic measurements were used to calculate a rate of $\mathrm{NADH}$ produced per minute per microgram of protein.

\section{mtDNA copy number assay}

To measure mitochondrial genome abundance relative to the nuclear genome, MCF-7L and TamR-MCF-7 cells were plated at 500,000 cells per $10 \mathrm{~cm}$ tissue culture dish, allowed to attach overnight, washed with PBS, and then treated with $10 \mathrm{nM}$ 4-hydroxytamoxifen or ethanol vehicle for 4 days in phenol red free IMEM with $5 \%$ steroid hormone depleted serum. Cells were then harvested by scraping after exposure to lysis buffer, and total RNase treated DNA was isolated using the Qiagen DNeasy kit according to the manufacturer's instructions. $1 \mu \mathrm{g}$ of DNA was used as template for qPCR amplification of mitochondrial DNA (a 125 bp portion of the cytochrome B coding sequence) and nuclear DNA (a 158 bp intron/ exon boundary spanning fragment of the pyruvate kinase gene) as described above.

\section{Statistical analysis}

Pairwise comparisons were subjected to Student T-tests using Microsoft Excel. Significant differences in experiments with multiple comparisons were evaluated using analysis of variance (ANOVA) followed by TukeyKramer Honest Significant Difference tests; this analysis was performed using JMP Pro Version 11.

\section{Results}

To determine whether cells selected for resistance to the SERM 4-hydroxytamoxifen (TamR-MCF-7) had cross resistance to the pure antiestrogen fulvestrant (ICI), cell cycle phase distribution was compared in TamR-MCF-7 and parental cells (MCF-7L) after treatment with vehicle or $1 \mathrm{nM}$ (ICI) in the presence of $5 \%$ fetal bovine serum. Vehicle treated TamR-MCF-7 cells had an increased G1 phase population and decreased S phase population compared with vehicle treated MCF-7L cells, reflecting a slower rate of proliferation. While MCF-7L cells had an increased fraction of cells in the G1 phase and a decreased fraction in S phase, TamR-MCF-7 cell cycle phase distribution was unaffected by treatment with ICI (Fig. 2a), indicating cross resistance to ICI developed with selection for 4-hyroxytamoxifen resistance. Because resistance to antiestrogen has been associated with resistance to chemotherapy agents (Skildum et al. 2011), we then compared sensitivity to doxorubicin by measuring 

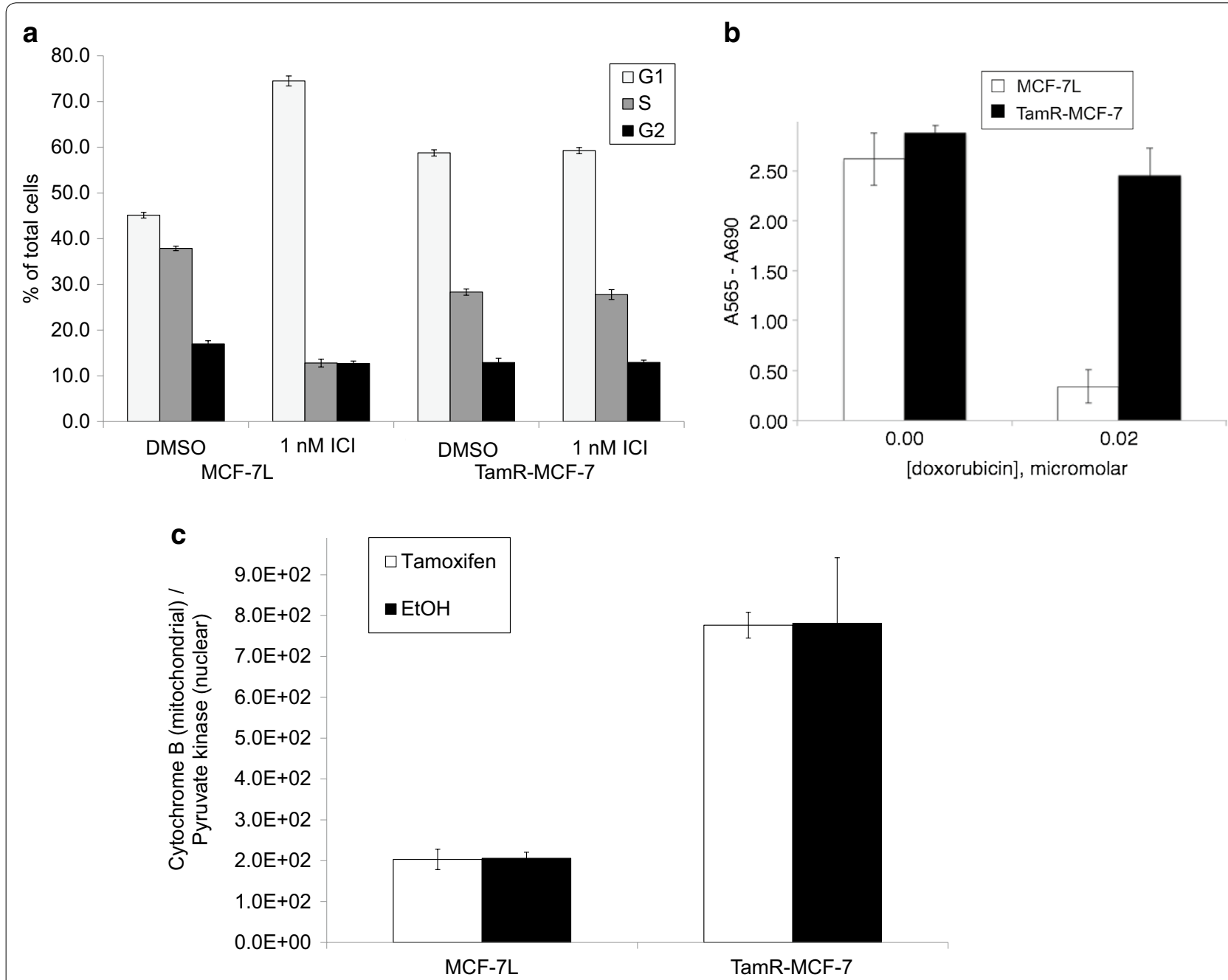

Fig. 2 Tamoxifen resistant breast cancer cells have elevated mitochondrial DNA and cross resistance to ICl and doxorubicin. a MCF-7L and TamRMCF-7 cells were treated for 2 days in $1 \mathrm{nM} \mathrm{ICl}$ or vehicle control (DMSO), then harvested and fixed in ethanol. Cell cycle phase distribution was determined by flow cytometric measurement of propidium iodide staining per cell. The average percentage of G1, S and G2/M cells are shown; error bars indicate one standard deviation $(n=3)$. b MCF-7L and TamR-MCF-7 cells were treated $\pm 0.02 \mathrm{~mm}$ doxorubicin. After 4 days, total cellular mass was measured by sulforhodamine B staining. The average SRB staining is shown; error bars indicate one standard deviation $(n=6)$. $\mathbf{c}$ MCF-7L and TamR-MCF-7 cells were treated for 2 days with $10 \mathrm{~nm}$ 4-hydroxytamoxifen or control (EtOH). Genomic DNA was extracted and used as template for detection of cytochrome B DNA on the mitochondrial genome and pyruvate kinase DNA on the nuclear genome. The average ratio of cytochrome $B$ to pyruvate kinase is shown; error bars indicate one standard deviation $(n=3)$

cell mass after treatment. While $0.02 \mu \mathrm{M}$ doxorubicin resulted in near complete cytotoxicity of MCF-7L cells, TamR-MCF-7 cell growth was not affected (Fig. 2b).

To test whether resistance to endocrine and chemotherapy may result from or cause a change in metabolic capacity, we next compared mitochondrial gene dose by quantitative PCR (qPCR) measurement of pyruvate kinase, encoded in nuclear DNA, and cytochrome B, encoded in mitochondrial DNA (mtDNA) (Fig. 2c). We found that TamR-MCF-7 cells had threefold higher mtDNA copy number than parental MCF-7L cells. The
mtDNA copy number was not altered by short term treatment with 4-hydroxytamoxifen in either cell line.

The elevated mtDNA copy number of TamR-MCF-7 cells suggests that a metabolic abnormality may be associated with the multi drug resistant phenotype in this model. To identify potential mediators of altered metabolism, expression of a panel of 81 genes that encode enzymes involved in carbohydrate metabolism was compared. MCF-7L and TamR-MCF-7 cells were serum starved, then treated with $1 \mathrm{nM} 17 \beta$-estradiol for 1 day. Total RNA was isolated and reverse transcribed to cDNA, 
which was used as template in pathway targeted qPCR arrays. The expression of three genes exceeded a twofold difference with statistical significance $(p<0.05)$ in TamR-MCF-7 cells: Glucokinase was expressed at lower levels in TamR-MCF-7, while phosphoglucomutase and PDK4 were expressed at higher levels in TamR-MCF-7 cells (Additional file 1: Figure S1). PDK4 encodes a regulatory kinase that phosphorylates and inhibits pyruvate dehydrogenase (PDH), a major determinant of substrate utilization in cells, and is the subject of the current study; the significance of glucokinase and phosphoglucomutase expression in this model will be explored separately.

To confirm the expression difference in PDK4, primers were designed to amplify an exon boundary spanning fragment of its cDNA (Table 2). PDK4 was measured in cDNA from cells treated identically to those used in the qPCR arrays (the 'validation set') using qPCR; $18 \mathrm{~s}$ rRNA was used to confirm equal loading. While the pathway targeted qPCR arrays revealed a two fold relative difference in PDK4, using single gene qPCR with quantitation based on a five point standard curve, we found that PDK4 mRNA was five times more abundant in TamR-MCF-7 relative to their parental cells, with no difference in $18 \mathrm{~s}$ rRNA (Fig. 3a).

The PDK4 promoter contains multiple glucocorticoid response elements. To test whether PDK4 expression was dependent on glucocorticoid receptor (GR) activity, we treated MCF-7L and TamR-MCF-7 with the GR agonist dexamethasone and the antagonist mifepristone in serum free media. To account for biological variability, triplicate cultures were prepared. In the cells treated with vehicle control (EtOH), we found elevated expression of PDK4 in TamR-MCF-7 cells (Fig. 3b), confirming our previous observations. While the GR ligands had no effect on PDK4 expression in MCF-7L cells, dexamethasone treatment resulted in an approximately five fold increase in PDK4 mRNA in TamR-MCF-7 cells. Mifepristone treatment alone caused a decrease in PDK4 expression in
TamR-MCF-7 cells, but the change was not statistically significant.

To test whether increased PDK4 mRNA expression is a general phenomenon or is specific to the TamR-MCF-7 model of acquired antiestrogen resistance, we tested the dexamethasone induction of PDK4 mRNA in an independent model. In contrast to TamR-MCF-7 cells direct selection for growth in the presence of 4-hydroxytamoxien in vitro, LCC9 cells were selected from MCF-7 cells first for estrogen independence in ovariectomized nude mice, then selected for ICI resistance in vitro (Brunner et al. 1997). Relative to their parental LCC-MCF-7 cells, LCC9 cells exhibited higher basal PDK4 mRNA expression; dexamethasone treatment resulted in a tenfold increase in PDK4 mRNA abundance when treated in serum free media (Fig. 3c).

PDK4 is known to inhibit PDH, resulting in decreased oxidation of glucose derived carbon in the tricarboxylic acid cycle. Physiologically this results in conservation of glucose as cells switch to oxidation of fatty acids and amino acids. We reasoned that by limiting the ability of cells to gain ATP through glycolysis by substituting galactose for glucose (Frey 1996), we could increase expression of PDK4 and test whether increased PDK4 expression resulted in altered sensitivity to SERMs and doxorubicin. MCF-7L and TamR-MCF-7 cells were cultured for 2 days in media containing fetal bovine serum and either $4.5 \mathrm{mg} / \mathrm{mL}$ glucose or $4.5 \mathrm{mg} / \mathrm{mL}$ galactose. PDK $4 \mathrm{mRNA}$ expression was measured by $\mathrm{qPCR}$, and PDK4 protein was measured by western blot. PDK4 mRNA expression was not altered by limiting the availability of glucose in either cell line (Fig. 1a). In contrast to the consistently elevated PDK4 mRNA observed in TamR-MCF-7, we found no difference in PDK4 protein detected by Western blot (Fig. 1b); Western blotting was challenging due to the consistent presence of non-specific background bands (indicated by black arrows in Fig. 1b). PDK4 protein was increased by culturing cells in galactose in both

Table 2 Primers

\begin{tabular}{|c|c|c|c|}
\hline Primer name & Length (BP) & Forward primer & Reverse primer \\
\hline 18 s rRNA for qPCR & 149 & 5' TCA ACT TTC GAT GGT AGT CGC CGT 3' & $5^{\prime}$ TCC TTG GAT GTG GTA GCC GTTTCT 3' \\
\hline$\beta$-actin mRNA for $\mathrm{qPCR}$ & 149 & $5^{\prime}$ GCC GCC AGC TCA CCA TGG AT 3' & $5^{\prime}$ CAC CAT CAC GCC CTG GTG CC $3^{\prime}$ \\
\hline PDK4 mRNA for qPCR & 119 & $5^{\prime}$ CCT GTG AGA CTC GCC AAC A 3' & $5^{\prime}$ TCC ACC AAA TCC ATC AGG CTC $3^{\prime}$ \\
\hline Cytochrome B genomic for qPCR & 125 & 5'-TGA TATTTC CTA TTC GCC TAC ACA-3' & 5'-TGTTGTTTG GAT ATA TGG AGG ATG-3' \\
\hline Pyruvate kinase genomic for $\mathrm{qPCR}$ & 158 & 5'-GTC GAT CCA GGA GAA CAT ATC AT-3 & 5'-CTC CTA GTTTTC ACC CTC ATT TTC-3' \\
\hline PDK4 genomic for sequencing & 367 & $5^{\prime}$ CAC TGA GAA TGT GAC CCG CT 3' & $5^{\prime}$ AGC CTT GTG TGA AGT AAC CTT AG 3' \\
\hline PDK4 cDNA for sequencing & 393 & 5' ATC CTC CCG ACC CAA TTA GT 3' & $5^{\prime}$ ACC CAC TGC TAC CAC ATC ACA $3^{\prime}$ \\
\hline
\end{tabular}

Sequences of primers used to measure expression of human PDK4 mRNA, b-actin mRNA, 18s rRNA, pyruvate kinase from the nuclear genome and cytochrome $B$ from the mitochondrial genom are shown along with sequencing primers for PDK4 using genomic DNA and CDNA templates 


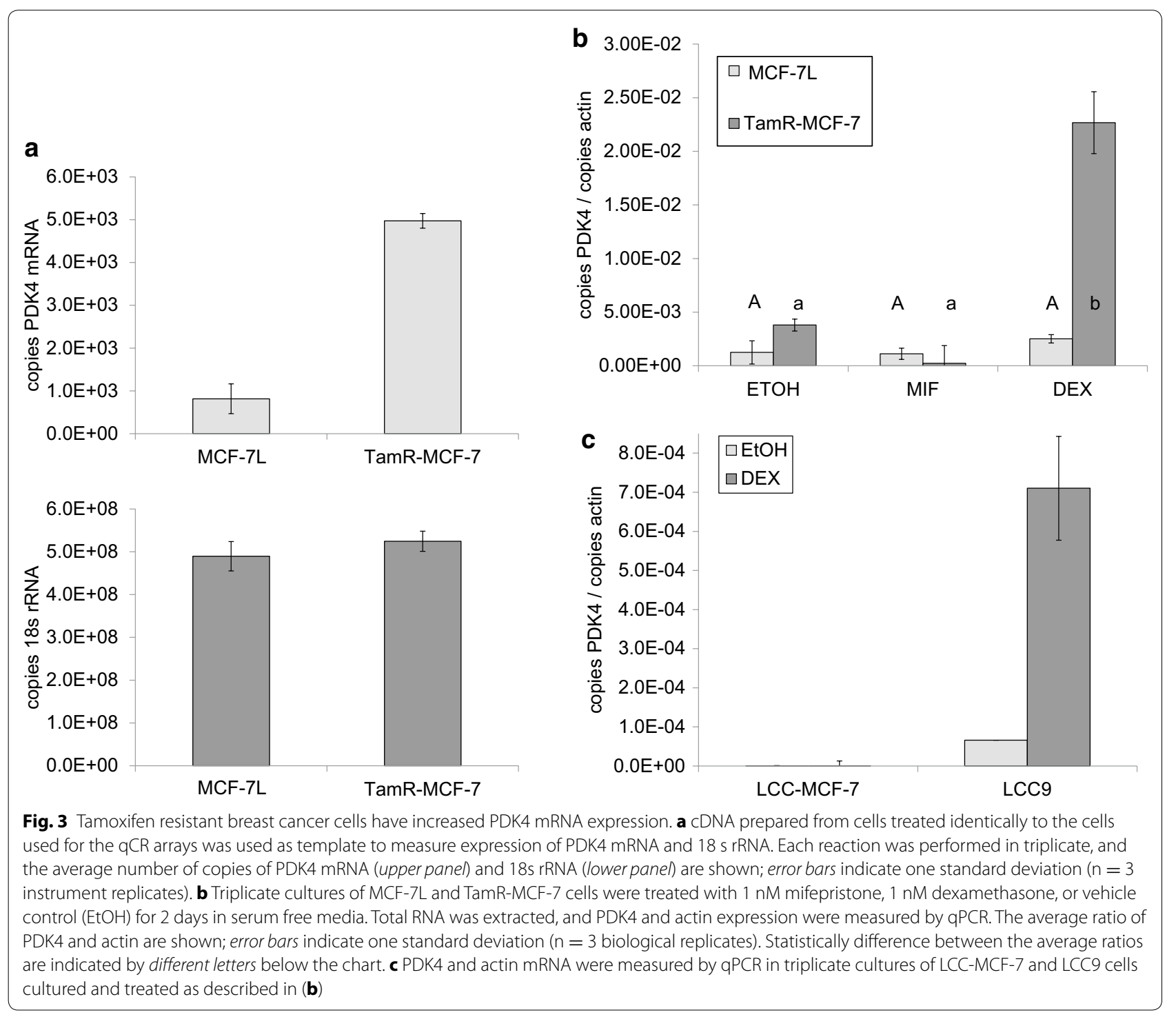

cell lines, but with a greater magnitude of change in drug sensitive MCF-7L cells.

To test the effects of carbohydrate substitution on drug sensitivity, ATCC-MCF-7 cells were adapted to growth in glucose limited conditions by culturing in progressively greater galactose and lower glucose concentrations until a population was derived that could grow as well in $4.5 \mathrm{mM}$ galactose as parental cells grew in $4.5 \mathrm{mM}$ glucose; these cells were designated MCF-7-GAL. To test whether ATP generated through glucose fermentation was required for sensitivity to antiestrogens, parental and MCF-7-GAL cells were treated with $1 \mathrm{nM} \mathrm{ICI}$; treatments were performed in both glucose or galactose media. Cell cycle phase distribution was then determined by DNA staining and flow cytometry (Fig. 4a). We found that parental MCF-7 cells were sensitive to ICI in both media, showing an increase in G1 phase cells and a decrease in S phase cells, though the degree of $\mathrm{G} 1$ arrest was reduced when treated in galactose. MCF-7-GAL cells had a reduced G1 and increased S phase fractions in the absence of ICI. MCF-7-GAL cells exhibited a G1 arrest with ICI treatment in both media, suggesting that the fermentation of glucose is not a determinant of SERM sensitivity in this model.

In contrast, adaptation to galactose resulted in decreased sensitivity to doxorubicin. Parental MCF-7 and MCF-7-GAL cells were treated with doxorubicin for 2 days, after which cell mass was measured by SRB staining. Galactose adapted cells had a smaller decrease in cell mass after treatment with either 0.15 or $0.6 \mu \mathrm{M}$ doxorubicin (Fig. 4b). 


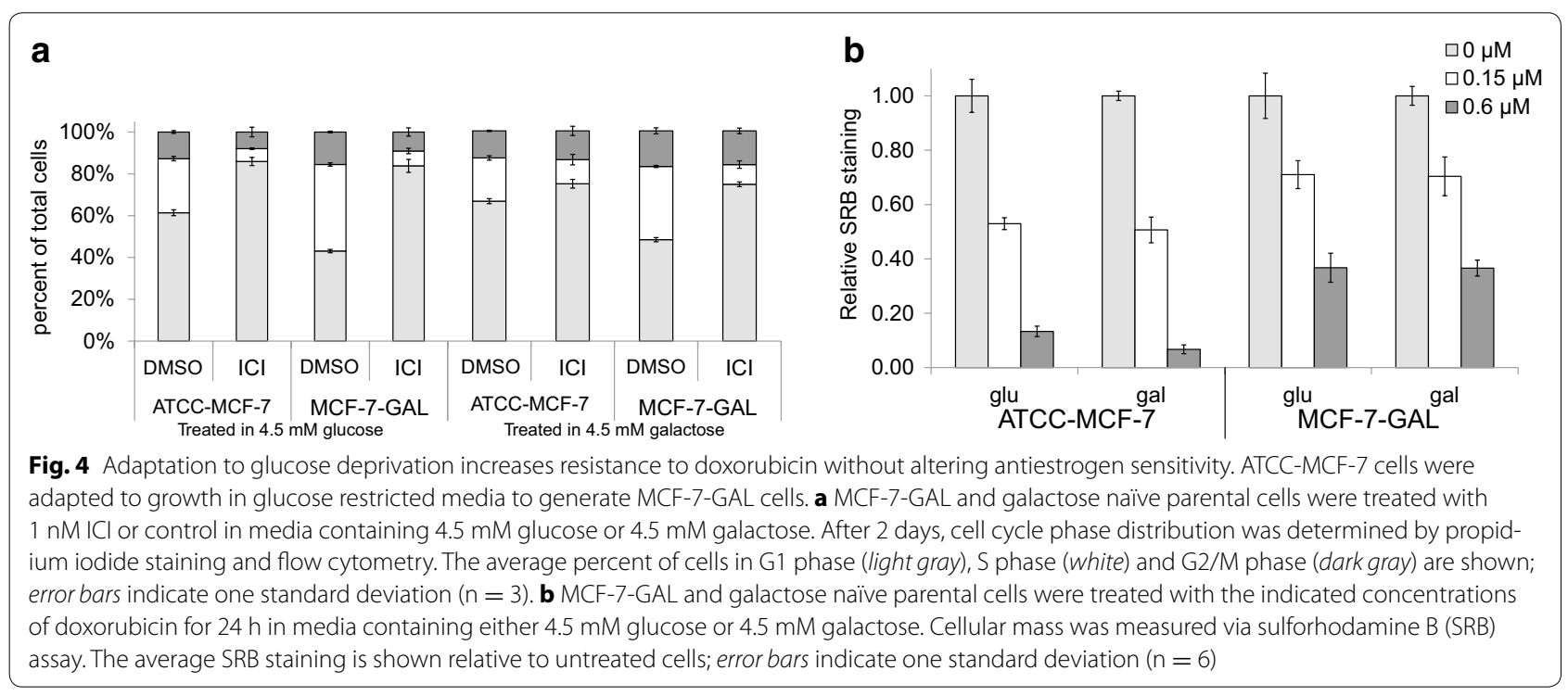

Because drug resistant TamR-MCF-7 cells had increased PDK4 mRNA but not PDK4 protein, we next compared the activity of $\mathrm{PDK} 4$ 's regulatory target, PDH. MCF-7L and TamR-MCF-7 cells were cultured in growth media, and lysates were prepared and subjected to an in vitro $\mathrm{PDH}$ activity assay that measured the rate of NADH generation. Cultures were prepared such that identical independent lysates could be prepared and the $\mathrm{PDH}$ assay conducted using fresh lysates on three consecutive days. Despite having greater expression of PDK4 mRNA, TamR-MCF-7 cells consistently had significantly elevated PDH activity compared to parental MCF-7L cells (Fig. 5; Additional file 1: Figure S2), suggesting TamRMCF-7 cells have a greater capacity to oxidize glucose.

Because TamR-MCF-7 cells had, paradoxically, elevated PDK4 mRNA expression and elevated PDH activity relative to their parental cells, we wondered if the TamR cells expressed an altered form of PDK4. The Catalogue of Somatic Mutations In Cancer (COSMIC) database (Forbes et al. 2008, 2015) reports that MCF-7 cells are heterozygous for a point mutation that results in a non-conservative alanine to threonine substitution at amino acid position 144. This position is in alpha helix \#7, near the PDK4 catalytic site (Wynn et al. 2008). We designed sequencing primers around this site (Table 2) and sequenced the region using cDNA and genomic DNA as template. We confirmed the heterozygous genotype reported in the COSMIC database in MCF-7L cells (Additional file 1: Figure S3). We found that TamRMCF-7 cells had loss of heterozygosity at this position; surprisingly TamR-MCF-7 were homozygous for the wild type PDK4 sequence.

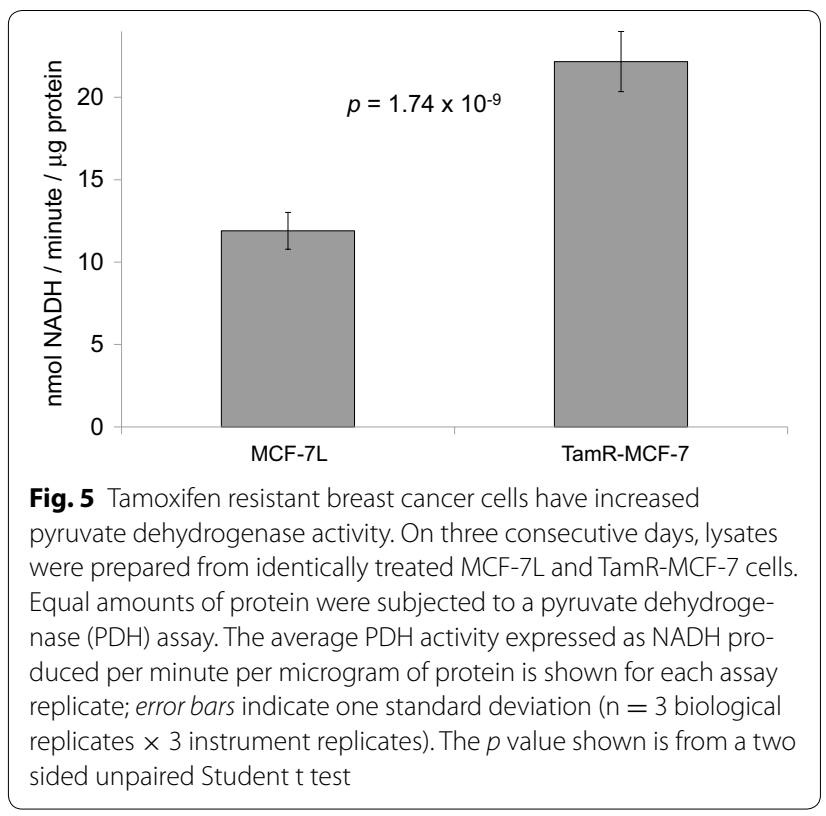

To test the functional significance of PDK4 expression on antiestrogen sensitivity, we used silencing RNA (siRNA) to knock down PDK4 expression in TamRMCF-7 cells. To validate the efficacy of the siRNA, TamR-MCF-7 cells were transfected with PDK4 or control siRNA, then treated with dexamethasone or vehicle control in media containing $5 \%$ FBS. RNA was isolated and reverse transcribed to CDNA, and the products used as template for qPCR amplification of PDK4 and actin (Fig. 6a). In these conditions, dexamethasone treatment 

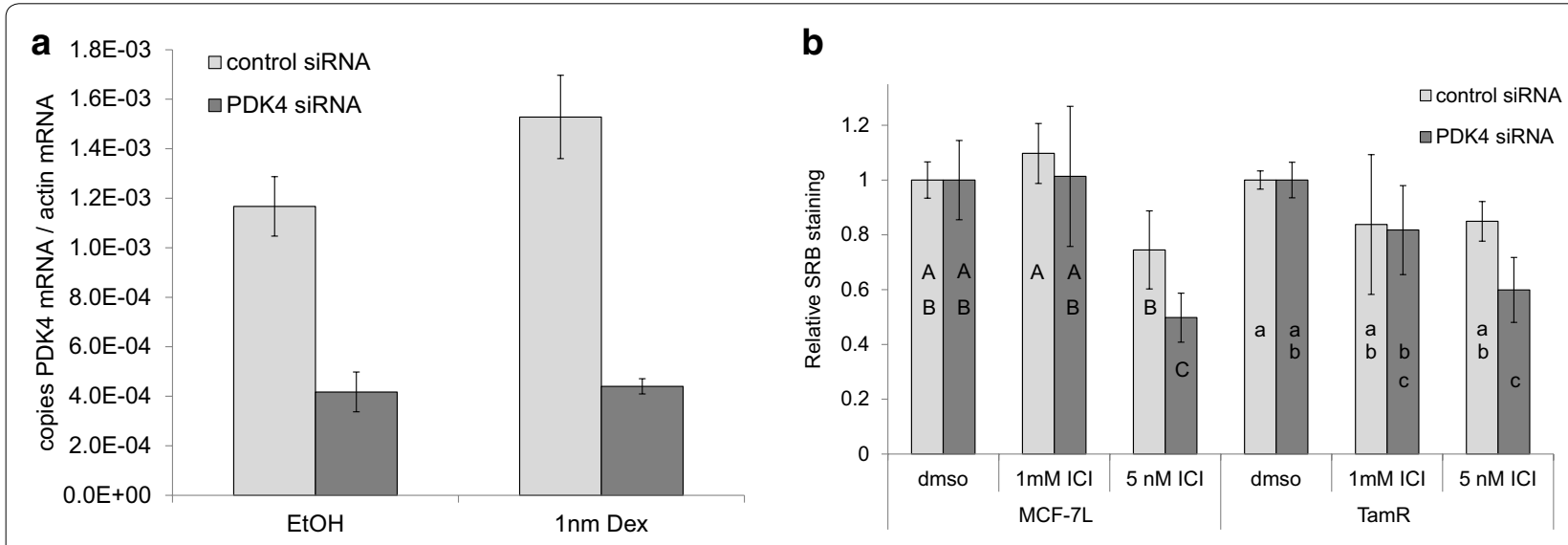

Fig. 6 Reducing PDK4 expression partially restores sensitivity to antiestrogen in tamoxifen resistant breast cancer cells. a TamR-MCF-7 cells were transfected with siRNA targeted to PDK4 or a non-specific control siRNA. The next day, they were treated with $1 \mathrm{~nm}$ dexamethasone in media containing fetal bovine serum. Two days later, total RNA was collected, and PDK4 and $\beta$-actin mRNA expression was measured by qPCR as described. The average ratio of PDK4 mRNA to $b$-actin mRNA is shown; error bars indicate one standard deviation ( $n=3$ biological replicates). $\mathbf{b}$ MCF-7L and TamR-MCF-7 cells were transfected with PDK4 or control siRNA. The next day, cells were treated with the indicated doses of ICl or vehicle control. After 4 days, cellular mass was measured by sulforhodamine B staining. The average SRB staining is shown relative to vehicle treated samples; error bars indicate one standard deviation $(n=4)$. Different letters indicate statistically significant differences determined by ANOVA and Tukey-Kramer honest significant differences comparisons

resulted in a smaller increase in PDK4 expression compared to treatment in serum free media (Fig. 2c).

TamR-MCF-7 cells were then transfected with PDK4 or control siRNA and treated with 1 or $5 \mathrm{nM} \mathrm{ICI}$ for 4 days, after which cellular abundance was measured by SRB staining. A small but reproducible and statistically significant increase in ICI sensitivity was observed with PDK4 siRNA relative to control siRNA at the highest $5 \mathrm{~nm}$ dose (Figs. 6b), suggesting PDK4 expression can mediate the responsiveness to SERMs. This observation was reproduced using a second siRNA targeting a different region of the PDK4 mRNA $3^{\prime}$ untranslated region (Additional file 1: Figure S4).

\section{Discussion}

The data presented above point to altered regulation of pyruvate dehydrogenase as mediating breast cancer cell sensitivity to estrogen receptor ligands such as tamoxifen and ICI, and reveal an important role for the serine threonine kinase PDK4 in acquired SERM resistance. PDK4 is reported to phosphorylate and inhibit $\mathrm{PDH}$, preventing the oxidation of carbon derived from glucose. When PDH is inactive, cells generate ATP through glycolysis, oxidation of amino acids and/or fatty acid oxidation. Rapidly dividing cells such as cancer cells require not only ATP but also carbon for biosynthesis, and the inhibition of PDH may allow glucose derived carbon to be conserved for biosynthesis of ribose sugars, amino acids, and glycerol, and the reduction of $\mathrm{NADP}^{+}$to NADPH. We show that sensitivity to SERMs is not affected by replacing glucose with galactose, a non-fermentable substrate. In contrast, galactose adapted cells showed resistance to the chemotherapy agent doxorubicin; this phenomenon has been reported previously in liver cancer cells (Marroquin et al. 2007).

PDK4 expression is transcriptionally regulated by numerous promoter elements, and its elevated mRNA in TamR-MCF-7 cells could indicate disruption of several signal transduction pathways. In a glioblastoma, Kim et al. describe PDK4 regulation through NF- $\mathrm{KB}$ activation of PGC1 $\alpha$ (Kim et al. 2015), and NF-kB signaling is altered in the LCC9 model of acquired SERM resistance (Riggins et al. 2005). Hypoxic signaling through estrogen related receptor gamma (ERR $\gamma$ ) also activates PDK4 transcription (Lee et al. 2012; Zhang et al. 2006), and ERR is directly inhibited by 4-hydroxytamoxifen, the most biologically potent tamoxifen metabolite (Coward et al. 2001; Tremblay et al. 2001). Knutson et al. report that PDK4 expression is dependent on progesterone receptor sumoylation in MCF-7 cells (Knutson et al. 2012), and progesterone receptor regulates breast cancer cell proliferation (Skildum et al. 2005). Mifepristone is an antagonist of both glucocorticoid receptors and progesterone receptors (Beck et al. 1993), though we did not observe statistically significant regulation of PDK4 mRNA by mifepristone in either MCF-7L or TamR-MCF-7 (Fig. 2b). Interestingly, TamR-MCF-7 express reduced progesterone receptor mRNA relative to their parental cells (Fagan et al. 2012).

PDK4 was first identified in a linkage study of loci associated with Type 2 diabetes mellitus in Native Americans 
(Rowles et al. 1996), and insulin is known to repress PDK4 transcription (Wu et al. 1998; Majer et al. 1998). Interestingly, in serum free media we show that the regulation of PDK4 by the glucocorticoid receptor agonist dexamethasone only occurs in drug resistant breast cancer cells (Fig. 2c), while the dexamethasone induction is dramatically blunted when TamR-MCF-7 cells are treated in the presence of fetal bovine serum (Fig. 7a; Additional file 1: Figure S4a). Insulin inhibits glucocorticoid dependent expression of PDK4 expression by preventing FOXO1 translocation to the nucleus (Kwon et al. 2004). Together these results suggest that in the absence of insulin and other growth factors in serum, parental MCF-7 cells have increased FOXO1 activity compared to TamR-MCF-7 cells, but that serum growth factors are still capable of blunting PDK4 expression by dexamethasone in these cells.

The consequences of PDK4 expression on cancer progression and response to therapy are likely to be context dependent. PDK4 was shown to be abundant in patient glioblastoma compared to normal tissue, and indirectly reducing its expression through shRNA targeting the RelA subunit of NF-kB resulted in reduced growth of xenografts in nude mice (Kim et al. 2015). Similarly, reducing PDK4 directly through shRNA resulted in increased tumor free survival of mice bearing prostate cancer cell xenografts (Liu et al. 2014). In contrast, in lung cancer cells decreasing PDK4 expression both prevented the antiproliferative action of a PPAR $\gamma$ agonist by blocking its action at the $\mathrm{G} 1 \rightarrow \mathrm{S}$ phase checkpoint (Srivastava et al. 2014) and promoted epithelial to mesenchymal transition and chemotherapy resistance. The latter effects may be due to PDK4 physically interacting with the mitochondrial apoptosis inducing factor (AIF) rather than its phosphorylation of PDH (Sun et al. 2014; Cande et al. 2002).

Although PDK4 mRNA is overexpressed in TamRMCF-7 cells relative to their tamoxifen naïve parental cells, PDK4 protein levels are similar and PDH activity is higher in TamR-MCF-7. These results suggest that PDK4 in TamR-MCF-7 is not acting as an inhibitor of PDH. Increased mRNA without increased protein level is consistent with decreased translation and/or increased protein turnover. If PDK4 protein turnover is increased in TamR-MCF-7 cells, the increased PDH activity in these cells may be result because PDK4 does not have time to be appropriately post-translationally modified or transported to the mitochondria. PDK4 has several sites identified as phosphorylated in proteomic screens (Franchin et al. 2015; Hornbeck et al. 2012), but the significance of these modifications with respect to PDK4 or PDH activity have not been characterized. Newly synthesized PDK4 may have reduced PDH inhibitory activity, and/or may act through targets other than PDH (e.g. AIF). These possibilities, and the significance of PDK4 polymorphisms, are currently under study.

\section{Additional file}

Additional file 1: Figure S1. Volcano plot showing glucose metabolism genes differently expressed in TamR-MCF-7 and parental MCF-7L. Expression of glucose metabolism genes were compared using qPCR arrays. Genes expressed higher in TamR-MCF-7 cells are represented by dots on the right side of the plot while genes expressed at lower levels in TamRMCF-7 are on the left side. qPCR arrays were performed on separately prepared triplicate cultures; the vertical axis shows the $p$ value for each gene. The dots representing phosphoglucomutase (PGM), glucokinase (GCK) and pyruvate dehydrogenase kinase -4 (PDK4) are indicated by gray circles. Figure S2. TamR-MCF-7 cells have increased pyruvate dehydrogenase activity relative to parental MCF-7L cells. On three consecutive days, lysates were prepared from identically treated MCF-7L and TamR-MCF-7 cells. Equal amounts of protein from each cell line were subjected to a pyruvate dehydrogenase $(\mathrm{PDH})$ assay. The average $\mathrm{PDH}$ activity expressed as NADH produced per minute per microgram of protein is shown for each assay replicate; error bars indicate one standard deviation $(n=3$ instrument replicates). Asterisks indicate significantly different $(p<0.05)$ averages as determined by unpaired two tailed Student's T tests. The numbers below each day indicate the amount of protein loaded in each assay. Figure S3. Tamoxifen resistant breast cancer cells have loss of heterozygosity at amino acid position 144 in the PDK4 protein. MCF-7L CDNA and genomic DNA was used as template for sequencing of the DNA around base position 430 of PDK4 mRNA. Forward and reverse reads are shown; wild type and mutant sequences are shown below. Figure S4. Reducing PDK4 expression partially restores sensitivity to antiestrogen in tamoxifen resistant breast cancer cells. A) TamR-MCF-7 cells were transfected with an siRNA targeting a different region of the PDK4 mRNA than that shown in Fig. 6 or a non-specific control siRNA. The next day, they were treated with $1 \mathrm{~nm}$ dexamethasone in media containing fetal bovine serum. Two days later, total RNA was collected, and PDK4 and $\beta$-actin mRNA expression was measured by qPCR as described. The average ratio of PDK4 mRNA to $\mathrm{b}$-actin mRNA is shown; error bars indicate one standard deviation ( $\mathrm{n}=3$ biological replicates). B) MCF-7L and TamR-MCF-7 cells were transfected with the PDK4 siRNA used in Figure S4A or control siRNA. The next day, cells were treated with the indicated doses of $\mathrm{ICI}$ or vehicle control. After four days, cellular mass was measured by sulforhodamine B staining. The average SRB staining is shown relative to vehicle treated samples; error bars indicate one standard deviation $(n=4)$. Different letters indicate statistically significant differences determined by ANOVA and Tukey-Kramer Honest Significant Differences comparisons.

\section{Authors' contributions}

WW: qPCR, PDH assays, sequencing. JT: cell cycle assays, siRNA transfections, LCC9 PDK4 expression. JB: characterize galactose adapted cells. DHF: made and characterized TamR-MCF-7 model. CZ: qPCR arrays. DY: made TamR-MCF-7 model. AS: SRB assays, Western blotting, lab PI, manuscript preparation. All authors read and approved the final manuscript.

\section{Author details}

${ }^{1}$ Department of Biomedical Sciences, University of Minnesota Medical School, Duluth Campus, Duluth, MN, USA. ${ }^{2}$ Masonic Cancer Center, University of Minnesota, Minneapolis, MN, USA.

\section{Acknowledgements}

LCC-MCF-7 and LCC9 cells were a gift from Dr. Robert Clarke of the Lombardi Cancer Center. The qPCR array experiment was supported by a Grant In Aid to A. S. from the University of Minnesota Office of the Vice President for Research. W. W. and C. Z. were supported by the University of Minnesota, Duluth Undergraduate Research Opportunities Program. J. T. and J. B. were supported by the University of Minnesota Medical School, Duluth Pathways to Advanced 
Degrees in Life Sciences program. The authors thank Dr. Lester Drewes and Mr. Jon Bredeson for helpful review of the manuscript.

\section{Competing interests}

The authors declare that they have no competing interests.

Received: 14 October 2015 Accepted: 19 October 2015

Published online: 10 November 2015

\section{References}

Abukhdeir AM, Vitolo MI, Argani P, De Marzo AM, Karakas B, Konishi H, Gustin JP, Lauring J, Garay JP, Pendleton C et al (2008) Tamoxifen-stimulated growth of breast cancer due to p21 loss. Proc Natl Acad Sci USA 105(1):288-293

Arpino G, De Angelis C, Giuliano M, Giordano A, Falato C, De Laurentiis M, De Placido S (2009) Molecular mechanism and clinical implications of endocrine therapy resistance in breast cancer. Oncology 77(Suppl 1):23-37

Bai RK, Chang J, Yeh KT, Lou MA, Lu JF, Tan DJ, Liu H, Wong LJ (2011) Mitochondrial DNA content varies with pathological characteristics of breast cancer. J Oncol 2011:496189

Banerji S, Cibulskis K, Rangel-Escareno C, Brown KK, Carter SL, Frederick AM, Lawrence MS, Sivachenko AY, Sougnez C, Zou L et al (2012) Sequence analysis of mutations and translocations across breast cancer subtypes. Nature 486(7403):405-409

Bayliss J, Hilger A, Vishnu P, Diehl K, El-Ashry D (2007) Reversal of the estrogen receptor negative phenotype in breast cancer and restoration of antiestrogen response. Clin Cancer Res 13(23):7029-7036

Beck CA, Estes PA, Bona BJ, Muro-Cacho CA, Nordeen SK, Edwards DP (1993) The steroid antagonist RU486 exerts different effects on the glucocorticoid and progesterone receptors. Endocrinology 133(2):728-740

Brinkman A, van der Flier S, Kok EM, Dorssers LC (2000) BCAR1, a human homologue of the adapter protein p130Cas, and antiestrogen resistance in breast cancer cells. J Natl Cancer Inst 92(2):112-120

Brockdorff BL, Heiberg I, Lykkesfeldt AE (2003) Resistance to different antiestrogens is caused by different multi-factorial changes and is associated with reduced expression of IGF receptor lalpha. Endocr Relat Cancer 10(4):579-590

Brunner N, Boysen B, Jirus S, Skaar TC, Holst-Hansen C, Lippman J, Frandsen T, Spang-Thomsen M, Fuqua SA, Clarke R (1997) MCF7/LCC9: an antiestrogen-resistant MCF-7 variant in which acquired resistance to the steroidal antiestrogen $\mathrm{ICI} 182,780$ confers an early cross-resistance to the nonsteroidal antiestrogen tamoxifen. Cancer Res 57(16):3486-3493

Buck MJ, Squire TL, Andrews MT (2002) Coordinate expression of the PDK4 gene: a means of regulating fuel selection in a hibernating mammal. Physiol Genom 8(1):5-13

Cande C, Cohen I, Daugas E, Ravagnan L, Larochette N, Zamzami N, Kroemer G (2002) Apoptosis-inducing factor (AIF): a novel caspase-independent death effector released from mitochondria. Biochimie 84(2-3):215-222

Chu I, Arnaout A, Loiseau S, Sun J, Seth A, McMahon C, Chun K, Hennessy B, Mills GB, Nawaz Z et al (2007) Src promotes estrogen-dependent estrogen receptor alpha proteolysis in human breast cancer. J Clin Investig 117(8):2205-2215

Cook CC, Higuchi M (2012) The awakening of an advanced malignant cancer: an insult to the mitochondrial genome. Biochim Biophys Acta 1820(5):652-662

Coward P, Lee D, Hull MV, Lehmann JM (2001) 4-Hydroxytamoxifen binds to and deactivates the estrogen-related receptor gamma. Proc Natl Acad Sci USA 98(15):8880-8884

DeBerardinis RJ, Lum JJ, Hatzivassiliou G, Thompson CB (2008) The biology of cancer: metabolic reprogramming fuels cell growth and proliferation. Cell Metab 7(1):11-20

Droog M, Beelen K, Linn S, Zwart W (2013) Tamoxifen resistance: from bench to bedside. Eur J Pharmacol 717(1-3):47-57

Early Breast Cancer Trialists' Collaborative G (2005) Effects of chemotherapy and hormonal therapy for early breast cancer on recurrence and 15-year survival: an overview of the randomised trials. Lancet 365(9472):1687-1717
Fagan DH, Uselman RR, Sachdev D, Yee D (2012) Acquired resistance to tamoxifen is associated with loss of the type I insulin-like growth factor receptor: implications for breast cancer treatment. Cancer Res 72(13):3372-3380

Forbes SA, Bhamra G, Bamford S, Dawson E, Kok C, Clements J, Menzies A, Teague JW, Futreal PA, Stratton MR (2008) The catalogue of somatic mutations in cancer (COSMIC). Curr Protoc Hum Genet Chapter 10:Unit 1011

Forbes SA, Beare D, Gunasekaran P, Leung K, Bindal N, Boutselakis H, Ding M, Bamford S, Cole C, Ward S et al (2015) COSMIC: exploring the world's knowledge of somatic mutations in human cancer. Nucleic Acids Res 43(Database issue):D805-D811

Franchin C, Cesaro L, Salvi M, Millioni R, lori E, Cifani P, James P, Arrigoni G, Pinna $L$ (2015) Quantitative analysis of a phosphoproteome readily altered by the protein kinase CK2 inhibitor quinalizarin in HEK-293T cells. Biochim Biophys Acta 1854(6):609-623

Frey PA (1996) The Leloir pathway: a mechanistic imperative for three enzymes to change the stereochemical configuration of a single carbon in galactose. FASEB J 10(4):461-470

Fujii R, Hanamura T, Suzuki T, Gohno T, Shibahara Y, Niwa T, Yamaguchi Y, Ohnuki K, Kakugawa Y, Hirakawa H et al (2014) Increased androgen receptor activity and cell proliferation in aromatase inhibitor-resistant breast carcinoma. J Steroid Biochem Mol Biol 144(Pt B):513-522

Han F, Miksicek R, Clarke R, Conrad SE (2004) Expression of an estrogen receptor variant lacking exon 3 in derivatives of MCF-7 cells with acquired estrogen independence or tamoxifen resistance. J Mol Endocrinol 32(3):935-945

Hanahan D, Weinberg RA (2011) Hallmarks of cancer: the next generation. Cell 144(5):646-674

Hiromasa Y, Hu L, Roche TE (2006) Ligand-induced effects on pyruvate dehydrogenase kinase isoform 2. J Biol Chem 281(18):12568-12579

Hornbeck PV, Kornhauser JM, Tkachev S, Zhang B, Skrzypek E, Murray B, Latham V, Sullivan M (2012) PhosphoSitePlus: a comprehensive resource for investigating the structure and function of experimentally determined post-translational modifications in man and mouse. Nucleic Acids Res 40(Database issue):D261-D270

Jordan VC, Koerner S (1975) Tamoxifen (ICI 46,474) and the human carcinoma 85 oestrogen receptor. Eur J Cancer 11(3):205-206

Jordan VC, O'Malley BW (2007) Selective estrogen-receptor modulators and antihormonal resistance in breast cancer. J Clin Oncol 25(36):5815-5824

Kato M, Chuang JL, Tso SC, Wynn RM, Chuang DT (2005) Crystal structure of pyruvate dehydrogenase kinase 3 bound to lipoyl domain 2 of human pyruvate dehydrogenase complex. EMBO J 24(10):1763-1774

Kim JW, Tchernyshyov I, Semenza GL, Dang CV (2006) HIF-1-mediated expression of pyruvate dehydrogenase kinase: a metabolic switch required for cellular adaptation to hypoxia. Cell Metab 3(3):177-185

Kim MY, Koh DI, Choi WI, Jeon BN, Jeong DY, Kim KS, Kim K, Kim SH, Hur MW (2015) ZBTB2 increases PDK4 expression by transcriptional repression of RelA/p65. Nucleic Acids Res 43(3):1609-1625

Knutson TP, Daniel AR, Fan D, Silverstein KA, Covington KR, Fuqua SA, Lange CA (2012) Phosphorylated and sumoylation-deficient progesterone receptors drive proliferative gene signatures during breast cancer progression. Breast Cancer Res 14(3):R95

Kwon HS, Huang B, Unterman TG, Harris RA (2004) Protein kinase B-alpha inhibits human pyruvate dehydrogenase kinase-4 gene induction by dexamethasone through inactivation of FOXO transcription factors. Diabetes 53(4):899-910

Lee JH, Kim EJ, Kim DK, Lee JM, Park SB, Lee IK, Harris RA, Lee MO, Choi HS (2012) Hypoxia induces PDK4 gene expression through induction of the orphan nuclear receptor ERRgamma. PLoS One 7(9):e46324

Lee Y, Dominy JE, Choi YJ, Jurczak M, Tolliday N, Camporez JP, Chim H, Lim JH, Ruan HB, Yang X et al (2014) Cyclin D1-Cdk4 controls glucose metabolism independently of cell cycle progression. Nature 510(7506):547-551

Lehn S, Ferno M, Jirstrom K, Ryden L, Landberg G (2011) A non-functional retinoblastoma tumor suppressor (RB) pathway in premenopausal breast cancer is associated with resistance to tamoxifen. Cell Cycle 10(6):956-962

Lipton A, Demers LM, Harvey HA, Kambic KB, Grossberg H, Brady C, Adlercruetz H, Trunet PF, Santen RJ (1995) Letrozole (CGS 20267). A phase I study of a new potent oral aromatase inhibitor of breast cancer. Cancer 75(8):2132-2138 
Liu Z, Chen X, Wang Y, Peng H, Wang Y, Jing Y, Zhang H (2014) PDK4 protein promotes tumorigenesis through activation of CAMP-response elementbinding protein (CREB)-Ras homolog enriched in brain (RHEB)-mTORC1 signaling cascade. J Biol Chem 289(43):29739-29749

Majer M, Popov KM, Harris RA, Bogardus C, Prochazka M (1998) Insulin downregulates pyruvate dehydrogenase kinase (PDK) mRNA: potential mechanism contributing to increased lipid oxidation in insulin-resistant subjects. Mol Genet Metab 65(2):181-186

Marroquin LD, Hynes J, Dykens JA, Jamieson JD, Will Y (2007) Circumventing the Crabtree effect: replacing media glucose with galactose increases susceptibility of HepG2 cells to mitochondrial toxicants. Toxicol Sci 97(2):539-547

Martinez-Outschoorn UE, Goldberg A, Lin Z, Ko YH, Flomenberg N, Wang C, Pavlides S, Pestell RG, Howell A, Sotgia F et al (2011) Anti-estrogen resistance in breast cancer is induced by the tumor microenvironment and can be overcome by inhibiting mitochondrial function in epithelial cancer cells. Cancer Biol Ther 12(10):924-938

Miller TW, Balko JM, Ghazoui Z, Dunbier A, Anderson H, Dowsett M, GonzalezAngulo AM, Mills GB, Miller WR, Wu H et al (2011) A gene expression signature from human breast cancer cells with acquired hormone independence identifies MYC as a mediator of antiestrogen resistance. Clin Cancer Res 17(7):2024-2034

Mora A, Davies AM, Bertrand L, Sharif I, Budas GR, Jovanovic S, Mouton V, Kahn CR, Lucocq JM, Gray GA et al (2003) Deficiency of PDK1 in cardiac muscle results in heart failure and increased sensitivity to hypoxia. EMBO J 22(18):4666-4676

Moy B, Specht MC, Lanuti M, Rafferty EA, Lerwill MF (2015) Case records of the Massachusetts General Hospital. Case 1-2015. A 66-year-old woman with metastatic breast cancer after endocrine therapy. N Engl J Med 372(2):162-170

Mukherjee S, Conrad SE (2005) c-Myc suppresses p21WAF1/CIP1 expression during estrogen signaling and antiestrogen resistance in human breast cancer cells. J Biol Chem 280(18):17617-17625

Oh AS, Lorant LA, Holloway JN, Miller DL, Kern FG, El-Ashry D (2001) Hyperactivation of MAPK induces loss of ERalpha expression in breast cancer cells. Mol Endocrinol 15(8):1344-1359

Osborne CK (1993) Mechanisms for tamoxifen resistance in breast cancer: possible role of tamoxifen metabolism. J Steroid Biochem Mol Biol 47(1-6):83-89

Osborne CK, Wiebe VJ, McGuire WL, Ciocca DR, DeGregorio MW (1992) Tamoxifen and the isomers of 4-hydroxytamoxifen in tamoxifen-resistant tumors from breast cancer patients. J Clin Oncol 10(2):304-310

Pilegaard H, Neufer PD (2004) Transcriptional regulation of pyruvate dehydrogenase kinase 4 in skeletal muscle during and after exercise. Proc Nutr Soc 63(2):221-226

Riggins RB, Zwart A, Nehra R, Clarke R (2005) The nuclear factor kappa B inhibitor parthenolide restores ICI 182,780 (Faslodex; fulvestrant)-induced apoptosis in antiestrogen-resistant breast cancer cells. Mol Cancer Ther 4(1):33-41

Rowles J, Scherer SW, Xi T, Majer M, Nickle DC, Rommens JM, Popov KM, Harris RA, Riebow NL, Xia J et al (1996) Cloning and characterization of PDK4 on $7 q 21.3$ encoding a fourth pyruvate dehydrogenase kinase isoenzyme in human. J Biol Chem 271(37):22376-22382

Scott GK, Kushner P, Vigne JL, Benz CC (1991) Truncated forms of DNA-binding estrogen receptors in human breast cancer. J Clin Investig 88(2):700-706

Shajahan-Haq AN, Cook KL, Schwartz-Roberts JL, Eltayeb AE, Demas DM, Warri AM, Facey CO, Hilakivi-Clarke LA, Clarke R (2014) MYC regulates the unfolded protein response and glucose and glutamine uptake in endocrine resistant breast cancer. Mol Cancer 13:239

Skildum A, Faivre E, Lange CA (2005) Progesterone receptors induce cell cycle progression via activation of mitogen-activated protein kinases. Mol Endocrinol 19(2):327-339

Skildum A, Dornfeld K, Wallace K (2011) Mitochondrial amplification selectively increases doxorubicin sensitivity in breast cancer cells with acquired antiestrogen resistance. Breast Cancer Res Treat 129(3):785-797

Soule HD, Vazguez J, Long A, Albert S, Brennan M (1973) A human cell line from a pleural effusion derived from a breast carcinoma. J Natl Cancer Inst 51(5):1409-1416
Srivastava N, Kollipara RK, Singh DK, Sudderth J, Hu Z, Nguyen H, Wang S, Humphries CG, Carstens R, Huffman KE et al (2014) Inhibition of cancer cell proliferation by PPARgamma is mediated by a metabolic switch that increases reactive oxygen species levels. Cell Metab 20(4):650-661

Strasser-Weippl K, Badovinac-Crnjevic T, Fan L, Goss PE (2013) Extended adjuvant endocrine therapy in hormone-receptor positive breast cancer. Breast 22(Suppl 2):S171-S175

Sun Y, Daemen A, Hatzivassiliou G, Arnott D, Wilson C, Zhuang G, Gao M, Liu P, Boudreau A, Johnson L et al (2014) Metabolic and transcriptional profiling reveals pyruvate dehydrogenase kinase 4 as a mediator of epithelial-mesenchymal transition and drug resistance in tumor cells. Cancer Metab 2(1):20

Tremblay GB, Bergeron D, Giguere V (2001) 4-Hydroxytamoxifen is an isoformspecific inhibitor of orphan estrogen-receptor-related (ERR) nuclear receptors beta and gamma. Endocrinology 142(10):4572-4575

Varma H, Skildum AJ, Conrad SE (2007) Functional ablation of pRb activates Cdk2 and causes antiestrogen resistance in human breast cancer cells. PLoS One 2(12):e1256

Wakeling AE, Dukes M, Bowler J (1991) A potent specific pure antiestrogen with clinical potential. Cancer Res 51(15):3867-3873

Wallez Y, Riedl SJ, Pasquale EB (2014) Association of the breast cancer antiestrogen resistance protein 1 (BCAR1) and BCAR3 scaffolding proteins in cell signaling and antiestrogen resistance. J Biol Chem 289(15):10431-10444

Wang L, Sahlin K (2012) The effect of continuous and interval exercise on PGC-1alpha and PDK4 mRNA in type I and type II fibres of human skeletal muscle. Acta Physiol 204(4):525-532

Wang C, Li Z, Lu Y, Du R, Katiyar S, Yang J, Fu M, Leader JE, Quong A, Novikoff PM et al (2006) Cyclin D1 repression of nuclear respiratory factor 1 integrates nuclear DNA synthesis and mitochondrial function. Proc Natl Acad Sci USA 103(31):11567-11572

Wells SA Jr, Santen RJ, Lipton A, Haagensen DE Jr, Ruby EJ, Harvey H, Dilley WG (1978) Medical adrenalectomy with aminoglutethimide: clinical studies in postmenopausal patients with metastatic breast carcinoma. Ann Surg 187(5):475-484

Wilcken NR, Prall OW, Musgrove EA, Sutherland RL (1997) Inducible overexpression of cyclin D1 in breast cancer cells reverses the growth-inhibitory effects of antiestrogens. Clin Cancer Res 3(6):849-854

Wu P, Sato J, Zhao Y, Jaskiewicz J, Popov KM, Harris RA (1998) Starvation and diabetes increase the amount of pyruvate dehydrogenase kinase isoenzyme 4 in rat heart. Biochem J 329(Pt 1):197-201

Wynn RM, Kato M, Chuang JL, Tso SC, Li J, Chuang DT (2008) Pyruvate dehydrogenase kinase-4 structures reveal a metastable open conformation fostering robust core-free basal activity. J Biol Chem 283(37):25305-25315

Yang N, Liu C, Peck AR, Girondo MA, Yanac AF, Tran TH, Utama FE, Tanaka T, Freydin B, Chervoneva I et al (2013) Prolactin-Stat5 signaling in breast cancer is potently disrupted by acidosis within the tumor microenvironment. Breast Cancer Res 15(5):R73

Zhang Y, Ma K, Sadana P, Chowdhury F, Gaillard S, Wang F, McDonnell DP, Unterman TG, Elam MB, Park EA (2006) Estrogen-related receptors stimulate pyruvate dehydrogenase kinase isoform 4 gene expression. J Biol Chem 281(52):39897-39906

\section{Submit your manuscript to a SpringerOpen ${ }^{\odot}$ journal and benefit from:}

- Convenient online submission

$\checkmark$ Rigorous peer review

- Immediate publication on acceptance

- Open access: articles freely available online

- High visibility within the field

- Retaining the copyright to your article

Submit your next manuscript at $>$ springeropen.com 